\title{
Modelling phase shifts in a rocky subtidal ecosystem
}

\author{
Jean-Sébastien Lauzon-Guay ${ }^{1, *}$, Robert E. Scheibling ${ }^{2}$, Myriam A. Barbeau ${ }^{1}$ \\ ${ }^{1}$ Biology Department, University of New Brunswick, Bag Service 45111, Fredericton, New Brunswick E3B 6E1, Canada \\ ${ }^{2}$ Biology Department, Dalhousie University, Halifax, Nova Scotia B3H 4J1, Canada
}

\begin{abstract}
The rocky subtidal ecosystem of the Atlantic coast of Nova Scotia is characterised by 2 community states, kelp beds and urchin barrens that alternate on a decadal time scale. While the shift from barrens to a kelp bed requires a large perturbation, namely a disease outbreak causing urchin mass mortality, the reverse shift is more gradual and mediated by the formation and propagation of destructive grazing aggregations (or fronts) of sea urchins Strongylocentrotus droebachiensis. We have developed a spatial model for the re-establishment of kelp beds and the formation of a feeding front of urchins in order to describe transitions (phase shifts) between kelp bed and barrens states following an urchin mass mortality event. Our model includes size-specific movement, growth, and survival of urchins, as well as growth of kelp and grazing by urchins. The position of the kelp bedbarrens interface (or grazing front) predicted by our model is in general agreement with field observations at 2 sites and for up to $7 \mathrm{yr}$ after a mass mortality event. Elasticity analysis showed that daily foraging movements by individual urchins have the greatest effect on the position of the feeding front and the density of the urchins there. Survival and recruitment rates of urchins also have large effects on urchin density at the front. The density of urchin populations in deep-water thermal refuges (from a disease agent) and the distance between these source populations and remnant or emergent kelp beds have large effects on the time required for the re-formation of a feeding front after an event of urchin mass mortality. These findings suggest that site-specific characteristics should be taken into account in the development of sustainable harvesting strategies and habitat-based management of the urchin fishery.
\end{abstract}

KEY WORDS: Alternative states $\cdot$ Feeding front $\cdot$ Sea urchins $\cdot$ Strongylocentrotus droebachiensis Kelp beds $\cdot$ Phase shifts $\cdot$ Population dynamics $\cdot$ Mathematical modelling

\section{INTRODUCTION}

The notion that biotic communities can exist in multiple alternative states at different times in the same place is well entrenched in ecology (Lewontin 1969, Holling 1973, Sutherland 1974, Knowlton 1992). Alternative states have been documented in various terrestrial (e.g. forests, grassland), freshwater (e.g. wetlands, lakes), and marine (e.g. rocky intertidal and subtidal communities, soft-bottom assemblages, coral reefs) systems (reviewed by Folke et al. 2004). Although many studies have addressed the potential for alternate stable states, relatively few have investigated the dynamics of transitions between states, particularly for spatially complex ecosystems. Understanding mechanisms that drive transitions (phase shifts) between alternative states is crucial in assessing the consequences of anthropogenic impacts and climate change on the structure and dynamics of ecosystems and the services that they provide to human societies (Hughes et al. 2005). To this end, mathematical models can provide a useful means of exploring various biotic and abiotic factors and processes that determine persistence of community states, as well as threshold levels of perturbations that can cause phase shifts. These models can be useful in generating hypotheses for future empirical and experimental work. They can also inform management policy in the face of multiple forms and escalating levels of anthropogenic impact.

A prime example of a shift between alternate community states is the transition that occurs when stands of macrophytes (seaweeds or sea grasses) are destruc- 
tively grazed by sea urchins (Camp et al. 1973, Lawrence 1975). On temperate rocky coasts worldwide, subtidal habitats are often characterised by 1 of 2 community states: kelp beds/forests or sea urchin barrens. Kelp beds or forests are characterised by high diversity and biomass of fleshy macroalgae and low densities of urchins. The upper canopy is composed of various genera of large kelps (e.g. Macrocystis, Nereocystis, Laminaria), while the understory consists of smaller foliose and turf-forming algae, sponges, bivalves, and a variety of other invertebrates (Dayton 1985, Steneck et al. 2002). In stark contrast, urchins are abundant in barrens, and their intensive grazing denudes the seabed of all but encrusting coralline red algae (Foreman 1977, Chapman \& Johnson 1990, Sivertsen 1997). In some areas, either community state may last for protracted periods (Estes \& Palmisano 1974), while, in other areas, more rapid transitional patterns have been observed (Scheibling 1986, Johnson \& Mann 1988).

The transition between kelp beds and urchin barrens is typically mediated by the destructive grazing of kelps and associated algae by sea urchins (Lawrence 1975). Through recruitment and/or migration, urchins accumulate at the margins of kelp beds, forming dense aggregations (grazing fronts) that can travel through kelp beds at speeds of up to $4 \mathrm{~m} \mathrm{mo}^{-1}$, leaving only coralline crusts in their wake (Scheibling et al. 1999). Wave action in shallow waters can interrupt the shoreward progression of urchin fronts, allowing a narrow fringe population of kelp to survive in the shallow subtidal zone (Keats 1991a). Urchins in the barrens behind a grazing front can survive indefinitely by feeding on corallines, microbial films, and drift algae (Johnson \& Mann 1982). Thus, the barrens state appears to have a high degree of stability as even low biomass of urchins (150 to $250 \mathrm{~g} \mathrm{~m}^{-2}$ ) can prevent the re-establishment of kelp beds (Breen \& Mann 1976, Chapman 1981). On the west coast of North America, over-exploitation of sea otters has likely increased the stability of the barrens state by releasing urchin populations from predatory controls (Simenstad et al. 1978).

Along the Atlantic coast of Nova Scotia, mass mortalities of the green sea urchin Strongylocentrotus droebachiensis have been scientifically documented since the 1980s (Scheibling \& Hennigar 1997, Miller \& Nolan 2000), and there is anecdotal evidence of these events in earlier decades (Miller 1985). These mortalities have been associated with the presence of a pathogenic amoeba Paramoeba invadens (Jones \& Scheibling 1985) that appears to be periodically introduced to the coast with intrusions of warm water in the late summer and fall (Scheibling \& Hennigar 1997). The growth and survival of this amoeba is temperature dependent (Jellett \& Scheibling 1988), and urchins in deep water (deeper than $20 \mathrm{~m}$, and below the seasonal thermocline at temperatures $<10^{\circ} \mathrm{C}$ ) have a thermal refuge from the disease (Brady \& Scheibling 2005). These episodic mass mortalities provide the only known perturbation that can drive the transition from urchin barrens to kelp beds in the area of the coast above $20 \mathrm{~m}$ depth.

Thus, mass mortalities of urchins in barrens due to disease, and the formation of grazing fronts at the margin of kelp beds, result in large fluctuations in urchin density that drive the alternation between the 2 community states of the shallow subtidal ecosystem. Understanding the mechanisms that determine the mode and tempo of these transitions is not only of general ecological interest, but also has important ecological implications for management of coastal resources. Kelp beds are deemed economically important habitats as they provide food and shelter for a variety of commercial species including lobster, Atlantic Canada's most valuable fishery (Beaudin 2001). In addition, a burgeoning sea urchin fishery was established along this coast in the late 1980s (Miller \& Nolan 2000). This fishery specifically targets urchin grazing fronts, and a habitat-based management policy was developed to control the transition between states through harvesting of urchins (Miller \& Nolan 2000).

With a long history of rigorous scientific investigation and a wealth of knowledge on the population biology and ecology of key species, the rocky subtidal ecosystem of Atlantic Nova Scotia is a prime subject for investigating transitions between alternate community states through mathematical modelling. Here, we present a spatial (1-dimensional) model of urchin and kelp dynamics, to investigate destructive grazing and transitions between the kelp bed and barrens state. In particular, we elucidate factors that affect the time to formation of a grazing front after a mass mortality event, and thereby determine the pace of transition. We compare our model predictions with field observations of front dynamics following mass mortality at 2 sites with contrasting bathymetry. We also compare population density and size structure of urchins predicted by our model to independent field observations. Lastly, we discuss the implications of our findings for the sustainable harvesting of sea urchins and habitat-based management of the fishery.

\section{MATERIALS AND METHODS}

Urchin dynamics. To capture the complex dynamics of the urchin-kelp system, we needed to incorporate both spatial and temporal components into our model. We previously showed that a simple model based on random foraging movement and food-dependent dis- 
persal of urchins, not only generates a feeding front in Strongylocentrotus droebachiensis, but also accurately predicts the dynamics (rate of advance, urchin density) of the front (Lauzon-Guay et al. 2008). Here, we used this foraging model as a framework for our model. Briefly, the foraging model is based on an integrodifference equation (Kot et al. 1996), with a Gaussian dispersal kernel to model the movement of urchins, such that:

$$
u_{t+1}(x)=\int k_{S}(x-y) u_{t}(y) \mathrm{d} y
$$

where $u_{t+1}(x)$ is the density of urchins (ind. $\mathrm{m}^{-2}$ ) at location $x$ at time $t+1$, and $k_{S}(x-y)$ is the redistribution kernel, dependent on food availability (subscript $S$ ), which gives the probability that an individual at position $y$ at time $t$ moves to position $x$ at time $t+1$. The redistribution kernel assumes that urchins remain stationary in the presence of food and redistribute when food is not available such that:

$$
k_{S}=\left\{\begin{array}{lll}
\delta(x-y) & \text { if } S_{t}(x)>0 \\
G(\mu, \sigma) & \text { if } S_{t}(x)=0
\end{array}\right\}
$$

where $\delta$ is the dirac delta function indicating no redistribution and $G$ is the Gaussian redistribution kernel of urchins that move with a specific mean $\mu$ and standard deviation $\sigma . S_{t}(x)$ is the biomass of $\operatorname{kelp}\left(\mathrm{kg} \mathrm{m}^{-2}\right)$ at location $x$ and time $t$.

We expanded this model to include multiple size classes of urchins. We used a matrix model (Caswell 2001) to account for size-specific survival and growth rates of urchins. An ontogenetic shift in behaviour occurs between juvenile and adult urchins. Juveniles of Strongylocentrotus droebachiensis tend to be sedentary, hiding in crevices and growing slowly until they reach 15 to $20 \mathrm{~mm}$ (test diameter). At this size, they begin to forage on attached algae in the open and to grow more rapidly and become reproductive (Rowley 1989, Dumont et al. 2004). Therefore, we divided our model population into 6 size classes of approximately equal range $(10 \mathrm{~mm}): u_{1}, u_{2}, u_{3}, u_{4}, u_{5}$, and $u_{6}$ corresponding to size classes of $<10,10$ to 19,20 to 29 , 30 to 39,40 to 49 and $\geq 50 \mathrm{~mm}$, respectively. Incorporating 2 juvenile classes in our model captured the early phase of slow growth, while the 4 adult classes enabled us to account for size-specific differences in grazing rate as well as the slower growth of urchins as they approach asymptotic size between 50 and $60 \mathrm{~mm}$ (Meidel \& Scheibling 1998).

We assigned size-specific probabilities for urchins in size class $i$ surviving $\left(s_{i}\right)$ and growing $\left(g_{i j}\right)$ into the next size class $j$. The probabilities of survival and growth can be combined to give the probability that an individual either survives and remains in its size class $-\left(1-g_{i j}\right) s_{i}=\alpha_{i i}$ - or survives and grows into the next size class $-g_{i j} S_{i}=\alpha_{i j}$. These transition probabilities and coefficients are placed in their appropriate positions in the transition matrix (A). The population dynamics of urchins (without spatial structure) can then be investigated from the following model:

$\mathbf{u}_{t+1}=\mathbf{A} \cdot \mathbf{u}_{t}=\left(\begin{array}{cccccc}\alpha_{11} & 0 & 0 & 0 & 0 & 0 \\ \alpha_{21} & \alpha_{22} & 0 & 0 & 0 & 0 \\ 0 & \alpha_{32} & \alpha_{33} & 0 & 0 & 0 \\ 0 & 0 & \alpha_{43} & \alpha_{44} & 0 & 0 \\ 0 & 0 & 0 & \alpha_{54} & \alpha_{55} & 0 \\ 0 & 0 & 0 & 0 & \alpha_{65} & \alpha_{66}\end{array}\right) \cdot\left(\begin{array}{c}u_{1} \\ u_{2} \\ u_{3} \\ u_{4} \\ u_{5} \\ u_{6}\end{array}\right)_{t}$

We substituted the number of urchins $u_{t}(x)$ in Eq. (3) with the spatially explicit population vector $\mathbf{u}_{t}(x)$ (Eq. 1), and the redistribution kernel $\left(k_{S}\right)$ (Eq. 2), with the redistribution matrix $\mathbf{M}_{S(x)}$ :

$\mathbf{M}_{S(x)}=\left(\begin{array}{cccccc}k_{1 S(x)} & 0 & 0 & 0 & 0 & 0 \\ k_{1 S(x)} & k_{2 S(x)} & 0 & 0 & 0 & 0 \\ 0 & k_{2 S(x)} & k_{3 S(x)} & 0 & 0 & 0 \\ 0 & 0 & k_{3 S(x)} & k_{4 S(x)} & 0 & 0 \\ 0 & 0 & 0 & k_{4 S(x)} & k_{5 S(x)} & 0 \\ 0 & 0 & 0 & 0 & k_{5 S(x)} & k_{6 S(x)}\end{array}\right)$

where $k_{i S(x)}$ is the redistribution kernel of urchins in size class $i$ as a function of the amount of food available $(S(x))$. We then included the spatial counterpart $\mathbf{A}_{S(x), \mathbf{u}(x)}$ of the transition matrix $\mathbf{A}$ to the integral to account for growth and survival of urchins in each size class at each location $x$ as a function of the food available $(S(x))$ and the number of urchins $(\mathbf{u}(x))$. We did not include recruitment coefficients in the transition matrix $\left(\mathbf{A}_{S(x), \mathbf{u}(x)}\right)$, because urchin larvae disperse widely in the plankton over several weeks (Strathmann 1978, Hart \& Scheibling 1988), and so it is unlikely that settlement rate would be correlated with the local population abundance. Instead, we used constant, habitat-specific recruitment rates, which reflected the lower settlement rate observed in kelp beds than in barrens $\left(17 \pm 7\right.$ and $44 \pm 20$ recruits $\mathrm{m}^{-2}$ [mean $\pm \mathrm{SE}$ ], respectively; Balch \& Scheibling 2000), and added a recruitment pulse term $R_{t, S(x)}$ once a year that is dependent on the kelp available at each position $x$. Altogether, our model for urchins is a sizestructured integro-difference equation (Neubert \& Caswell 2000):

$$
\mathbf{u}_{t+1}(x)=\int \mathbf{A}_{S(y), \mathbf{u}(y)}{ }^{\circ} \mathbf{M}_{S(y)}(x-y) \mathbf{u}_{t}(y) \mathrm{d} y+R_{t, S(x)}
$$

where $\circ$ is the Hadamard product indicating elementwise multiplication. 
Kelp dynamics. We modelled abundance of kelp (Laminaria spp.) in terms of biomass (rather than density) using a model similar to the one presented in Lauzon-Guay et al. (2008). Specifically, kelp growth was modelled using Ricker's model (Turchin 2003) with an added term for grazing, such that:

$S_{t+1}(x)=\max \left(S_{t}(x) \mathrm{e}^{r\left(1-\frac{S_{t}(x)}{K}\right)}-H_{t}(x) \sum_{i=3}^{6}\left(w_{i} \mathbf{u}_{i t}(x)\right), 0\right)$

where $S_{t}(x)$ is biomass of kelp at position $x$ and time $t$, $r$ is intrinsic growth rate of kelp, and $K$ is kelp carrying capacity (Table 1). The second part of Eq. (6) accounts for urchins grazing kelp, where $H_{t}(x)$ is a grazing function, $w_{i}$ is the weight of an urchin at the midpoint $\left(p_{i}\right)$ of size class $i$ given by $w_{i}=0.001 p_{i}^{2.7793}$ (Lauzon-Guay \& Scheibling 2007a). During simulations, if the amount of kelp grazed was greater than the amount of kelp available, kelp biomass was set to zero; this ensured kelp biomass does not become negative. As previously mentioned, juveniles are cryptic and do not feed actively on standing kelp, so we did not include them in the grazing function (i.e. $i=3$ to 6 ). Urchins in natural fronts have a grazing rate $(g)$ of $0.03 \mathrm{~g} \mathrm{kelp} \mathrm{g}^{-1}$ urchin $\mathrm{d}^{-1}$ (range: 0.009 to $0.046 \mathrm{~g} \mathrm{kelp} \mathrm{g}^{-1}$ urchin d $^{-1}$; Scheibling et al. 1999), but only if the urchin to kelp ratio is above a certain threshold value $(\sim 2 \mathrm{~kg}$ urchin $\mathrm{m}^{-2}$; Breen \& Mann 1976, Scheibling et al. 1999). At densities below this threshold, urchins are incapable of collectively weighing down kelp fronds to effectively graze them. Assuming urchins are grazing a kelp bed with a typical maximum biomass of $4 \mathrm{~kg}$ kelp $\mathrm{m}^{-2}$ (Mohn \& Miller 1987), we used 0.5 (2 kg urchin $\mathrm{m}^{-2} /$

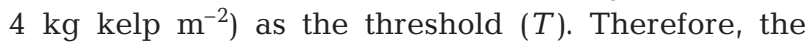
grazing function $H$ was defined as:

$$
H=\left\{\begin{array}{c}
g \text { if } \frac{\sum_{i=3}^{6} w_{i} \mathbf{u}_{i t}(x)}{S_{t}(x)}>T \\
0 \text { if } \frac{\sum_{i=3}^{6} w_{i} \mathbf{u}_{i t}(x)}{S_{t}(x)} \leq T
\end{array}\right\}
$$

We did not model explicitly the re-establishment of kelp beds after urchin mass mortality. There is insufficient information on advective dispersal of kelp spores, saltation, and density-dependent germination and fertilization success to adequately estimate parameters of a spatial-explicit model. We assumed that kelp can disperse over large distances (Gaylord et al. 2004), and that an initial kelp biomass of $50 \mathrm{~g} \mathrm{~m}^{-2}$ is present on the substratum at the beginning of the simulation in the area between the kelp bed and the refuge population (20 m depth) after an urchin mass mortality event. We used this small initial value of kelp biomass to obtain a kelp biomass of $\sim 10 \%$ of the carrying capacity $(K)$ after $1 \mathrm{yr}$ and a return to $90 \%$ of the carrying capacity within 3 yr of urchin mass mortality. Similar kelp growth rates were observed at several sites in Nova Scotia following removal of urchins (Scheibling 1986, Johnson \& Mann 1988).

Parameterization of the model. Although urchins have indeterminate growth, their growth is often modelled using an asymptotic model (Ebert \& Russell 1993, Meidel \& Scheibling 1998, Lamare \& Mladenov 2000, Brady \& Scheibling 2005). Size-specific growth rates were obtained from size-at-age relationships available for Strongylocentrotus droebachiensis in Nova Scotia (Meidel \& Scheibling 1998). Specifically, these authors modelled urchin size using logistic growth curves, such that:

$$
D=\frac{D_{0} D_{\infty}}{D_{0}+\left(D_{\infty}-D_{0}\right) \mathrm{e}^{-b D_{\infty} q}}
$$

where $D$ is test diameter $(\mathrm{mm}), D_{0}$ is the test diameter at settlement $(\mathrm{mm}), D_{\infty}$ is the asymptotic test diameter, $b$ is a growth constant, and $q$ is age (yr). To obtain growth rates, we used the first derivative of $D$ in Eq. (8) with respect to $q$ :

$$
\frac{\mathrm{d} D}{\mathrm{~d} q}=\frac{D_{0} D_{\infty}^{2}\left(D_{\infty}-D_{0}\right) b \mathrm{e}^{-b D_{\infty} q}}{\left(D_{0}+\left(D_{\infty}-D_{0}\right) \mathrm{e}^{-b D_{\infty} q}\right)^{2}}
$$

We then rearranged Eq. (8) to obtain the age $(q)$ at size $(D)$ and substituted $q$ in Eq. (9) by $q$ in Eq. (8) to obtain size-dependent growth rates. Growth parameters are available for 3 sub-populations of $S$. droebachiensis (Meidel \& Scheibling 1998), resulting in habitatspecific and size-specific growth rates (Table 1). To use these urchin growth rates in our model, a threshold kelp biomass of $100 \mathrm{~g} \mathrm{~m}^{-2}$ was selected as the cut-off point between kelp bed and barrens. If kelp biomass was above this threshold value and the urchin to kelp ratio was above the feeding threshold $(T=0.5)$, then urchins were considered to be in a grazing front and growth rates were selected accordingly. To obtain growth probabilities for the transition matrix, we divided the growth rate of individuals at the mid-point of each size class by the width of a size class (Barbeau \& Caswell 1999).

Size-specific survival rates are not readily available for Strongylocentrotus droebachiensis, but field surveys suggest that adult survival varies between 74 and $96 \%$ over a year (Russell et al. 1998, Chen \& Hunter 2003). Therefore, we used a mean value of $84 \%$ sur- 
Table 1. Descriptions, units, and values of parameters used in the sea urchin Strongylocentrotus droebachiensis and kelp models. Values in parentheses represent either standard error or range

\begin{tabular}{|c|c|c|c|c|c|c|c|}
\hline \multirow{2}{*}{ Symbol } & \multirow{2}{*}{ Description } & \multirow{2}{*}{ Unit } & \multirow[b]{2}{*}{ Overall } & \multirow{2}{*}{$\begin{array}{l}\text { Valu } \\
\text { Barrens }\end{array}$} & \multirow{2}{*}{ Front } & \multirow[b]{2}{*}{ Kelp bed } & \multirow{2}{*}{ Source } \\
\hline & & & & & & & \\
\hline $\mathbf{A}$ & Transition matrix & & & & & & \\
\hline$\alpha_{i j}$ & Matrix element & & & & & & \\
\hline$b$ & Urchin growth constant & $\mathrm{mm}^{-1} \mathrm{yr}^{-1}$ & & 0.020 & 0.018 & 0.014 & Meidel \& Scheibling (1998) \\
\hline$D_{0}$ & $\begin{array}{l}\text { Diameter of urchins at } \\
\text { settlement }\end{array}$ & $\mathrm{mm}$ & 2 & & & & Meidel \& Scheibling (1998) \\
\hline$D_{\infty}$ & $\begin{array}{l}\text { Asymptotic urchin test } \\
\text { diameter }\end{array}$ & $\mathrm{mm}$ & & 52 & 56 & 54 & Meidel \& Scheibling (1998) \\
\hline$g$ & Urchin grazing rates & $\begin{array}{l}\text { g kelp g-1 } \\
\text { urchin } d^{-1}\end{array}$ & $\begin{array}{c}0.030 \\
(0.009-0.046)\end{array}$ & & & & Scheibling et al. (1999) \\
\hline$H$ & $\begin{array}{l}\text { Grazing function of } \\
\text { urchins }\end{array}$ & $\begin{array}{l}g \text { kelp g }{ }^{-1} \\
\text { urchin } d^{-1}\end{array}$ & & & & & \\
\hline$K$ & $\begin{array}{l}\text { Carrying capacity of } \\
\text { kelp bed }\end{array}$ & g kelp $\mathrm{m}^{-2}$ & 4780 & & & & $\begin{array}{l}\text { Lauzon-Guay \& Scheibling } \\
\text { (2007a) }\end{array}$ \\
\hline$k_{i}$ & $\begin{array}{l}\text { Dispersal kernel of urchin } \\
\text { size class } i\end{array}$ & & & & & & \\
\hline $\mathbf{M}$ & Redistribution matrix & & & & & & \\
\hline$p_{i}$ & $\begin{array}{l}\text { Mid-point of urchin } \\
\text { size class } i\end{array}$ & $\mathrm{~mm}$ & $\begin{array}{l}5,15,25 \\
35,45,55\end{array}$ & & & & \\
\hline$q$ & Age of urchin & yr & & & & & \\
\hline$R$ & Urchin recruitment & ind. $\mathrm{m}^{-2}$ & & $17(7)$ & $17(7)$ & $44(20)$ & Balch \& Scheibling (2000) \\
\hline$r$ & Intrinsic growth rate of kelp & $\ln \left(\mathrm{d}^{-1}\right)$ & & & & & Mann (1972) \\
\hline$s_{1-2}$ & $\begin{array}{l}\text { Survival of urchins } \\
\text { in Classes } 1 \& 2\end{array}$ & $\% \mathrm{yr}^{-1}$ & $62.0(2.5)$ & & & & $\begin{array}{l}\text { Raymond \& Scheibling } \\
\text { (1987) }\end{array}$ \\
\hline$s_{3-6}$ & $\begin{array}{l}\text { Survival of urchins in } \\
\text { Classes } 3 \text { to } 6\end{array}$ & $\% \mathrm{yr}^{-1}$ & $84.0(3.3)$ & & & & $\begin{array}{l}\text { Russell et al. (1998), Chen \& } \\
\text { Hunter (2003) }\end{array}$ \\
\hline$S_{t}(x)$ & $\begin{array}{l}\text { Biomass of kelp at a given } \\
\text { time and position }\end{array}$ & g & & & & & \\
\hline$T$ & Feeding threshold & & 0.5 & & & & \\
\hline $\mathbf{u}$ & Population vector & & & & & & \\
\hline$w_{i}$ & Mass of urchin in size class $i$ & $g$ & & & & & \\
\hline$x$ & Position & $\mathrm{m}$ & & & & & \\
\hline$y$ & Position & $\mathrm{m}$ & & & & & \\
\hline$\mu$ & $\begin{array}{l}\text { Mean of daily displacement } \\
\text { distribution of urchins } \\
>20 \mathrm{~mm} \text { test diameter }\end{array}$ & $\mathrm{m}$ & 0 & & & & Dumont et al. (2006) \\
\hline$\sigma$ & $\begin{array}{l}\text { Standard deviation of } \\
\text { displacement distribution } \\
\text { of urchins }\end{array}$ & $\mathrm{m}$ & 1.33 & & & & Dumont et al. (2006) \\
\hline
\end{tabular}

vival for adult urchins (>20 mm) over a year in our model. Survival of juvenile urchins $(<20 \mathrm{~mm})$ was estimated at $62.0 \%( \pm 2.5 \%, \mathrm{SE})$ annually in Nova Scotia (Raymond \& Scheibling 1987). The recruitment rate of $S$. droebachiensis is difficult to predict as it can vary greatly both spatially and temporally (Balch \& Scheibling 2000). As already mentioned, we used constant, habitat-specific recruitment rates in our model.

We estimated the probability distribution of daily dispersal distances from observed displacements of marked urchins in barrens after $24 \mathrm{~h}$ (Dumont et al. 2006), using a Gaussian distribution with a mean of 0 and a standard deviation of 1.33 (Lauzon-Guay et al. 2008). Although urchins are able to detect food and move toward it, field observations suggest that displacement is non-directional (Dumont et al. 2004, Lauzon-Guay et al. 2006, Lauzon-Guay \& Scheibling 2007b); thus, our displacement distribution is symmetrical about 0 , with the same probability of moving toward or away from shore. Only urchins $>20 \mathrm{~mm}$ are redistributed in our model, since juveniles are sedentary and cryptic.

Model analyses. Validation: We simulated the reformation of a feeding front following a mass mortality event of urchins at 2 sites along the coast of Nova Sco- 
tia. The last episode of mass mortality at both sites occurred in September 1999, when all urchins died at $<20 \mathrm{~m}$ depth. The 2 sites are in close proximity $(<3.5 \mathrm{~km})$, but differ markedly in their depth profile. Chebucto Head $\left(44^{\circ} 30.165^{\prime} \mathrm{N}, 6^{\circ} 31.159^{\prime} \mathrm{W}\right)$ has a fairly steep slope $\left(\sim 20^{\circ}\right)$, while Splitnose Point $\left(44^{\circ} 28.609^{\prime} \mathrm{N}, 63^{\circ} 32.741^{\prime} \mathrm{W}\right)$ has a gradual slope $\left(\sim 4^{\circ}\right)$. This difference in slope determined the offshore distance over which urchins died during the mass mortality event.

For all simulations, we used a $500 \mathrm{~m}$ long domain divided into $2^{12}$ intervals of $\sim 0.1 \mathrm{~m}$ and with reflective boundaries. The time steps were set at 1 , and the model was run for $1500 \mathrm{~d}(\sim 4 \mathrm{yr})$ at Chebucto Head and 2500 d $(\sim 7$ yr) at Splitnose Point. Simulations were done using the fast Fourier transform algorithm in MATLAB.

For simulations of Chebucto Head, we chose initial conditions to mimic the state of the system following mass mortality of Strongylocentrotus droebachiensis, with only a deep population of urchins remaining (Brady \& Scheibling 2005). Specifically, the spatial domain was divided such that, at $t=0$, kelp was abundant from 0 to $100 \mathrm{~m}$ ( $8 \mathrm{~m}$ depth) and barrens existed from 100 to $500 \mathrm{~m}$. Urchins were not present from 0 to $150 \mathrm{~m}$ (20 m depth), and normal barrens densities of urchins were found from 150 to $500 \mathrm{~m}$ (where depth would exceed $20 \mathrm{~m}$, given the bottom slope). The urchins, therefore, had to travel $50 \mathrm{~m}$ to reach the kelp bed. We compared the time for the re-formation of a feeding front at the lower limit of the kelp bed obtained from our simulation to that observed by Brady \& Scheibling (2005). We also compared the simulated size distribution of urchins in the barrens and front sub-populations to observed distributions.

For simulations of Splitnose Point, we estimated that the depth refuge for the urchin population $(>20 \mathrm{~m}$ depth), based on a bottom slope of $\sim 4^{\circ}$, was located $120 \mathrm{~m}$ offshore of the position of the front (at $12 \mathrm{~m}$ depth) observed in July 2005 (Lauzon-Guay \& Scheibling 2007a). The lower limit of the kelp bed at Splitnose Point in 1999 is not known, but, if we assume that it was similar to that at Chebucto Head ( $8 \mathrm{~m}$ depth), the bottom distance between the surviving urchin population below $20 \mathrm{~m}$ and the full kelp bed would have been $180 \mathrm{~m}$. Therefore, between September 1999 and July 2005, the kelp bed would have extended $60 \mathrm{~m}$ and the urchin population would have moved $120 \mathrm{~m}$. A year later, in July 2006, the front had advanced $11 \mathrm{~m}$ shoreward, consuming the kelp bed (Lauzon-Guay \& Scheibling 2007a). We ran a simulation with these initial conditions (i.e. with the refuge urchin population $180 \mathrm{~m}$ from the kelp bed) and compared the position of the front and the density of urchins at the front observed in 2005 and 2006 with model predictions.
Uncertainty analysis: We conducted uncertainty analysis to assess the amount of variation in the model predictions (i.e. urchin density and cumulative front advance) at both sites, given the natural variation observed in the parameters. This was done by running 200 simulations for each site and resampling parameter space using a Monte Carlo method. At the beginning of each simulation, we randomly selected a value for parameters of the model, for which we had a measure of variation $\left(r, g, \sigma, R\right.$, and $\left.s_{i}\right)$, from their corresponding distributions based on the mean and standard error of each parameter estimate (Table 1). For $r$ and $R$, we used a gamma distribution, which has a lower bound at 0 (Evans et al. 2000). For $s_{i}$, we used a beta distribution, because $s_{i}$ is bounded between 0 and 1 (Evans et al. 2000). For g, we used a uniform distribution for the range of observed values, because we did not have information on the variance associated with grazing rates. For $\sigma$, we generated a distribution of values using a bootstrap procedure by redrawing individual urchin displacements (Manly 1997). We used the percentile method (Manly 1997) to evaluate the $95 \%$ confidence interval of the model output.

Factors affecting time needed for front formation: Using site conditions representative of Chebucto Head, we ran simulations with various levels of recruitment, initial density in the refuge population, and daily displacement of urchins (linear distance between the initial and final positions of an urchin over $1 \mathrm{~d}$ ) to evaluate their effect on the time needed for re-formation of a grazing front. We started simulations without any surviving urchins to test the effect of recruitment. We also ran simulations using various distances between the lower limit of the kelp bed and the surviving urchin population. We ran these latter simulations with and without recruitment to assess the change in the relative importance of recruitment and movement of urchins on the formation of a feeding front with varying distances. In all simulations, we did not include kelp re-colonization in the barrens because we were interested in evaluating the effect of various parameters on the ability of urchins to migrate a specific distance (and form a front).

Elasticity analysis: We conducted an elasticity analysis on 2 model outputs: density of urchins at the front and position of the front $2 \mathrm{yr}$ after the start of the model (after mass mortality). Elasticity analysis was done numerically as:

$$
E_{\mathrm{p}}=100 \frac{X_{\mathrm{p}}-X_{0}}{X_{0}}
$$

where $E_{\mathrm{p}}(\%)$ is the elasticity of (or proportional change in) the output to a $10 \%$ increase in parameter $\mathrm{p}, X_{0}$ is the output of the original model, and $X_{\mathrm{p}}$ 
is the output of the model with parameter $p$ modified (Barbeau \& Caswell 1999). We used as initial conditions those observed at Chebucto Head in September 1999. For size-specific parameters (growth and survival of urchins), we did the analysis both for each size class separately and for all size classes simultaneously, to account for possible correlations in growth and survival between size classes.

\section{RESULTS}

\section{Chebucto Head}

Our model simulation predicted that Strongylocentrotus droebachiensis reached the lower margin of the pre-existing kelp bed in $<2$ yr after the mass mortality of urchins in the shallow zone in September 1999. By July 2002, our simulated front was at the position observed for the natural front in March 2003 (i.e. 8 mo ahead). Thus, by March 2003, our model predicted that the kelp bed should have receded 24 m (95\% CI: 20 to $32 \mathrm{~m}$ ) from its 1999 level, 9 m (95\% CI: 5 to $17 \mathrm{~m}$ ) more than observed (Fig. 1). Although our model predicted that urchins reached the lower

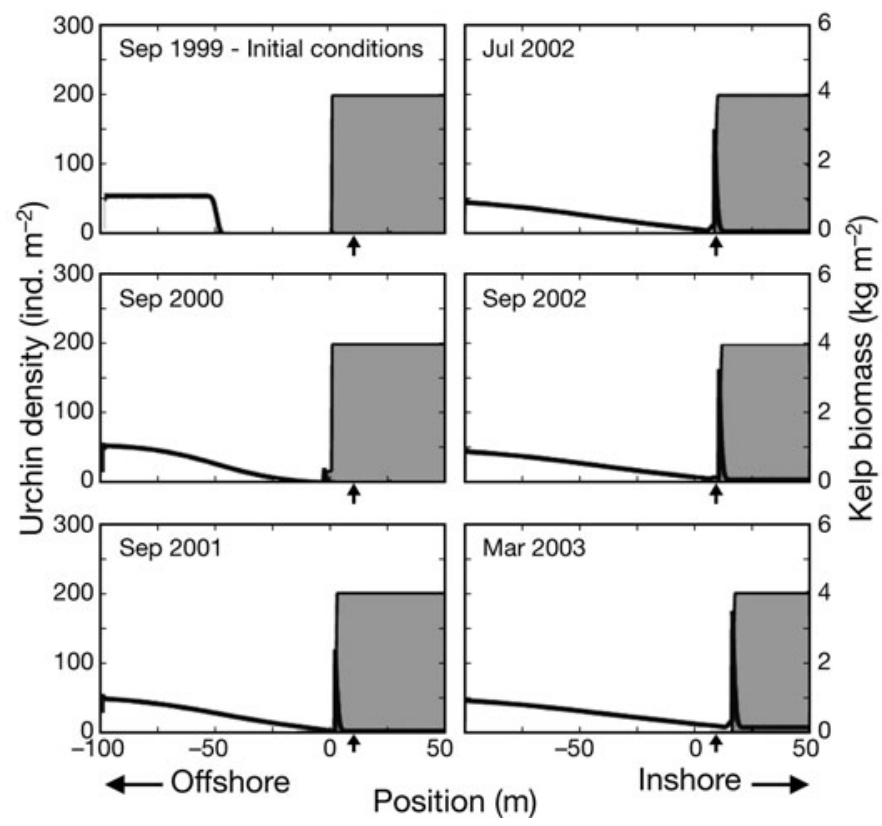

Fig. 1. Strongylocentrotus droebachiensis. Results of model simulations with initial conditions similar to those observed at Chebucto Head following the urchin mass mortality event in September 1999. Thick black line represents predicted adult urchin density (left $y$-axis), and the gray area represents predicted kelp biomass (right $y$-axis). Negative values on the $x$-axis represent distances offshore from the lower margin of the kelp bed in September 1999. Arrows indicate the observed position of the urchin front in March 2003 margin of the kelp bed after 200 d (March 2000), urchin density at this time was below the threshold required for destructive grazing. Based on our simulation, it took 340 d (September 2000) for urchin density at the kelp-barrens interface to exceed the threshold value and for an active grazing front to form and advance through the kelp bed (Fig. 2A,C). Initially, the model predicted a rapid increase in the advance of the front, followed by a stationary period, before a more gradual increase occurred. This was likely caused by the initial low kelp biomass that allowed for a rapid advance of the front. As kelp biomass ahead of the front increased, the advance of the front slowed until more urchins reached the front. Then, as urchin density at the front increased further and the ratio of urchin biomass to kelp biomass increased, the advance of the front gradually increased (Fig. 2C). In 2001, 3 yr after the mass mortality, the front travelled at $16.8 \mathrm{~m} \mathrm{yr}^{-1}$. The rate of advance of the front was linearly correlated to urchin density at the front for densities above the threshold (Pearson's $\left.r_{1197}=0.98, \mathrm{p}<0.001\right)$.

Our model predicted that urchin density should be lower in the newly formed barrens (20 to 30 urchins $\mathrm{m}^{-2}$ ) than in older barrens (60 to 80 urchins $\mathrm{m}^{-2}$ ) (Fig. 1). A similar pattern was observed at Chebucto Head, where urchin density was lower at $12 \mathrm{~m}$ depth (new barrens, 47 urchins $\mathrm{m}^{-2}$ ) than at $24 \mathrm{~m}$ depth (old barrens, 81 urchins $\mathrm{m}^{-2}$ ) (Brady \& Scheibling 2005). Our model also predicted a high urchin density at the front in March 2003 (190 urchins $\mathrm{m}^{-2}, 95 \% \mathrm{CI}$ : 111 to 317 urchins $\mathrm{m}^{-2}$; Fig. 2), which is $14 \%$ more than the urchin density observed at the leading edge of the front at Chebucto Head during the same period (166 urchins $\mathrm{m}^{-2}$; Brady \& Scheibling 2005).

Our model also predicted marked differences in the size structure of urchins among sub-populations $3 \mathrm{yr}$ after the mass mortality event (Fig. 3). The predicted size distribution in the kelp bed was composed mainly of small juveniles $\left(u_{1}\right)$ (Fig. 3A). The size distribution of urchins in the kelp bed was not quantified in the field, precluding a direct comparison. A bimodal size distribution was predicted in the grazing front, with the primary mode in the large adult size class $\left(u_{6}\right)$ and a smaller mode in the $<10 \mathrm{~mm}$ size class (Fig. 3B). While there is some disagreement with the smallest size class, the predicted size structure at the grazing front compared relatively well with that observed in the field at Chebucto Head in October 2002; in both cases, most urchins were in the 3 largest size classes (Fig. 3B). The presence of a secondary mode in the small juvenile size class in the front predicted by our model is likely because some recruitment occurred in the kelp bed and the front merged with those recruits as it advanced. Our model 


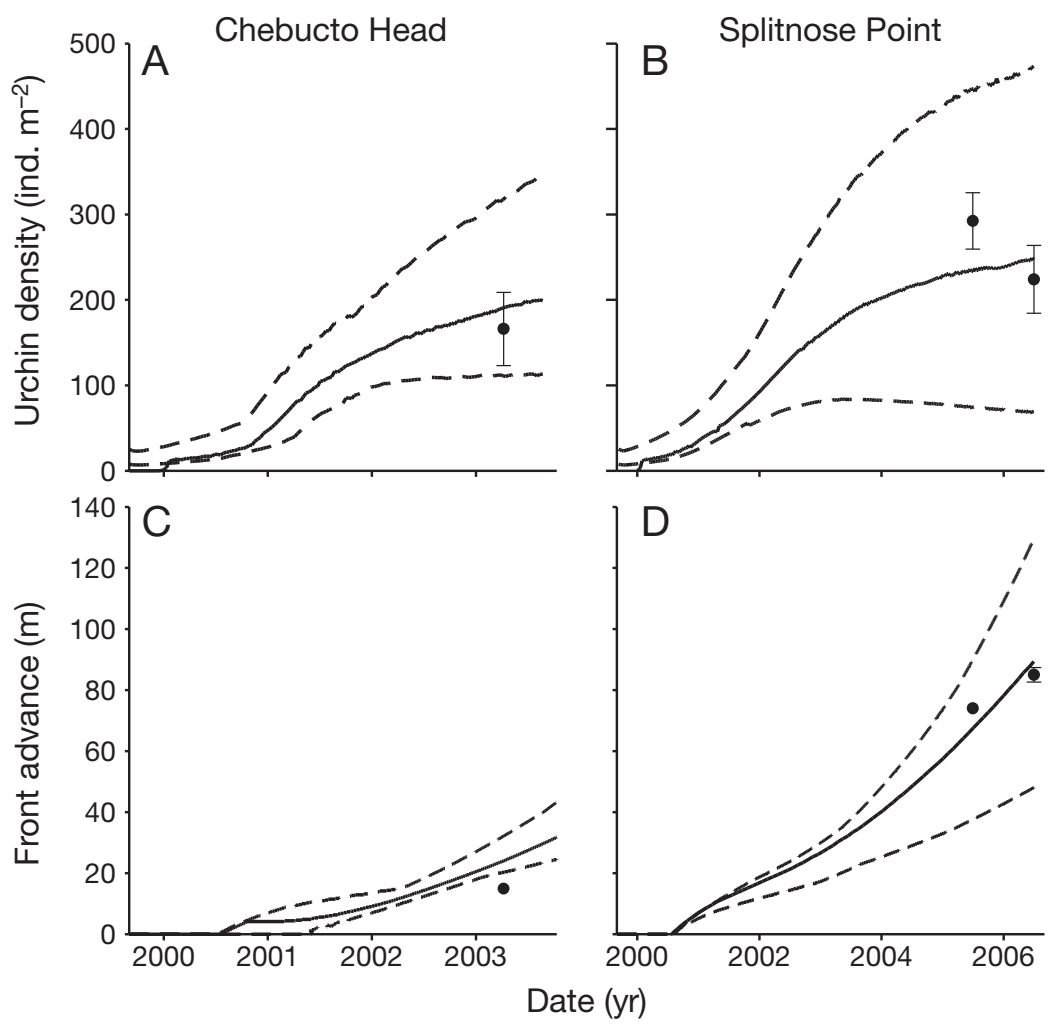

Fig. 2. Strongylocentrotus droebachiensis. $(\mathrm{A}, \mathrm{B})$ Density of urchins at the front and $(\mathrm{C}, \mathrm{D})$ cumulative front advance (solid lines) and $95 \%$ confidence intervals (dashed lines) for simulations using initial conditions at Chebucto Head $(A, C)$ and Splitnose Point $(B, D)$ following the urchin mass mortality event in September 1999. Filled circles represent field observations (mean $\pm 95 \%$ CI) from Chebucto Head in March 2003 (Brady \& Scheibling 2005) and Splitnose Point in July 2005 and July 2006 (Lauzon-Guay \& Scheibling 2007a). In Panels A and B, the broad confidence intervals about predictions of urchin density are a result of the uncertainty associated with our parameter estimates (especially recruitment, growth, and displacement of urchins) and the long time scale of our predictions lished kelp bed (Fig. 4). Changes in urchin density and front advance followed a similar dynamic as at Chebucto Head (Figs. 2B,D \& 4). In September 2004, 5 yr after the incidence of urchin mass mortality, biomass of the newly formed kelp bed had reached carrying capacity (Fig. 4). The model predicted that the urchin front reached $12 \mathrm{~m}$ depth in November 2005 or 6.2 yr after the mass mortality event (4 mo later than from our field observations). By July 2005 (the start of our field observations), the model predicted that the front was $7 \mathrm{~m}$ behind (95\% CI: $34 \mathrm{~m}$ behind to $20 \mathrm{~m}$ ahead) the actual position from field observations in 2005. A year later (July 2006), the model predicted that the front was $5 \mathrm{~m}$ ahead (95\% CI: $34 \mathrm{~m}$ behind to $46 \mathrm{~m}$ ahead) of its observed position in the field (Fig. 2D). Our model also predicted a high density of urchins in the front both in July 2005 (233 urchins $\mathrm{m}^{-2}, 95 \% \mathrm{CI}: 75$ to 447 urchins $\mathrm{m}^{-2}$ ) and 2006 (247 urchins $\mathrm{m}^{-2}, 95 \% \mathrm{CI}: 69$ to 473 urchins $\mathrm{m}^{-2}$ ), which is in agreement with field observations (292 and 224 urchins $\mathrm{m}^{-2}$ for July 2005 and 2006, respectively; Lauzon-Guay \& Scheibling 2007a) and corresponds to a 20 and $10 \%$ difference between observed and predicted values, respectively. also predicted a bimodal size distribution in the barrens, with a primary mode in the small juvenile size class $\left(u_{1}\right)$ and a secondary mode in the large adult size class $\left(u_{6}\right)$ (Fig. $3 \mathrm{C}$ ). The juvenile size class $\left(u_{1}\right)$ was overrepresented in the model when compared with field observations at Chebucto Head (Fig. 3C) (see 'Discussion, Spatial population dynamics').

\section{Splitnose Point}

After the mass mortality event in September 1999, urchins in the deeper refuge population at Splitnose Point had to travel a greater distance to encounter the kelp bed than those at Chebucto Head. This provided time for the kelp bed to grow to its carrying capacity in areas that were previously in the barrens state. After $1 \mathrm{yr}$, our simulation showed that a small aggregation of urchins formed at the lower limit of the newly estab-

\section{Factors affecting time needed for front formation}

The time required for re-formation of a grazing front was dependent on the linear extent of the urchin dieoff (i.e. the along-bottom distance between the lower margin of the kelp bed and the refuge population of urchins) (Fig. 5). Our model predicted that a front formed immediately (within $11 \mathrm{~d}$ ) when the urchin population was in contact with the kelp bed, but that it can take up to $1023 \mathrm{~d}$ for a front to re-form when the distance urchins must travel was $>100 \mathrm{~m}$ (Fig. 5). This maximum period was predicted when recruitment rather than migration of urchins was the main source of urchins in the front. When the distance exceeded $100 \mathrm{~m}$, the time required by urchins to reach the kelp bed was greater than the time required for recruits to grow into the third size class and forage on the standing kelp fronds. The importance of recruitment increased with the distance between the refuge popula- 

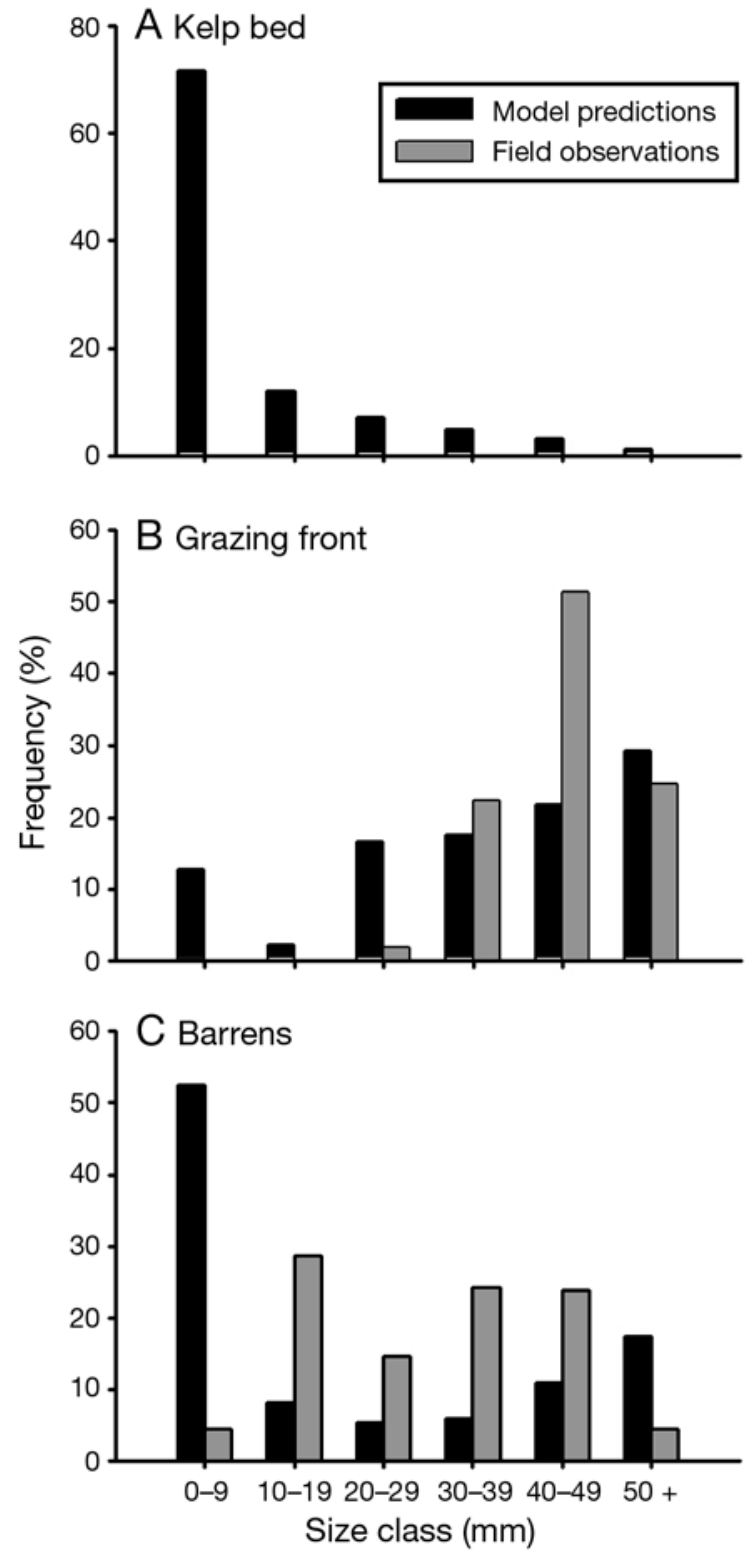

Fig. 3. Strongylocentrotus droebachiensis. Size-frequency distribution of urchins according to the spatial model at $t=1120 \mathrm{~d}$ (October 2002) at Chebucto Head for each sub-population(A) kelp bed, (B) grazing front, and (C) barrens - and field observations for (B) front and (C) barrens only (Brady \& Scheibling 2005). Field observations not available for (A) kelp bed

tion and the kelp bed (Fig. 5). For a distance $<50 \mathrm{~m}$, it took the same amount of time for a front to form with and without recruitment. At $75 \mathrm{~m}$, the time delay was $20 \%$ greater without than with recruitment (Fig. 5).

Clearly, the intensity of recruitment should influence the time to re-formation of a front. In simulations with different levels of recruitment and without any urchins at the beginning, the time to front formation decreased with increasing recruit density (Fig. 6A).
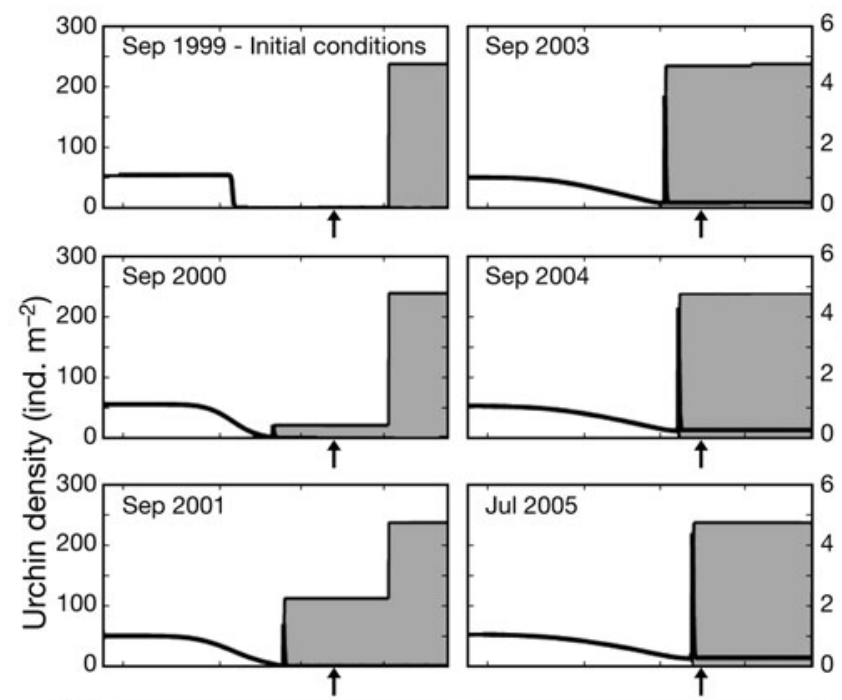

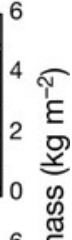
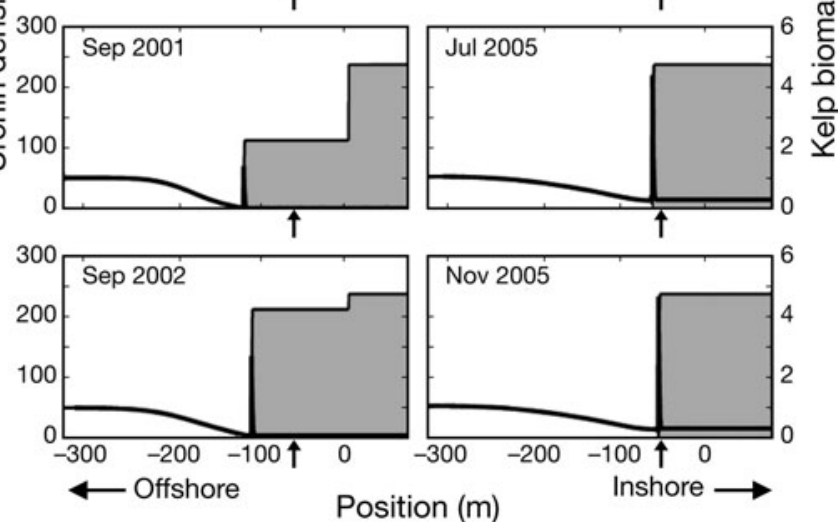

Fig. 4. Strongylocentrotus droebachiensis. Results of model simulations with initial conditions similar to those observed at Splitnose Point following the urchin mass mortality event in September 1999. Thick black line represents predicted adult urchin density (left $y$-axis), and the gray area represents predicted kelp biomass (right $y$-axis). Negative values on the $x$-axis represent distances offshore from the lower margin of the kelp bed in September 1999. Arrows indicate the observed position of the urchin front at the site in July 2005

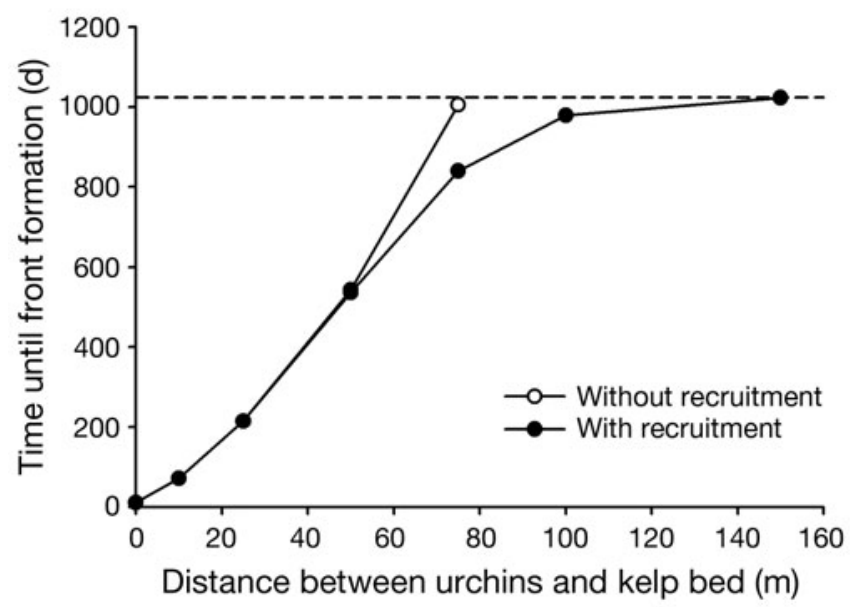

Fig. 5. Strongylocentrotus droebachiensis. Effect of distance between the deep urchin population and the kelp bed on time required for formation of a feeding front at the lower margin of the kelp bed. The dashed line represents time required (1023 d) for front formation when all urchins are removed and only recruitment is responsible for the increase in urchins 

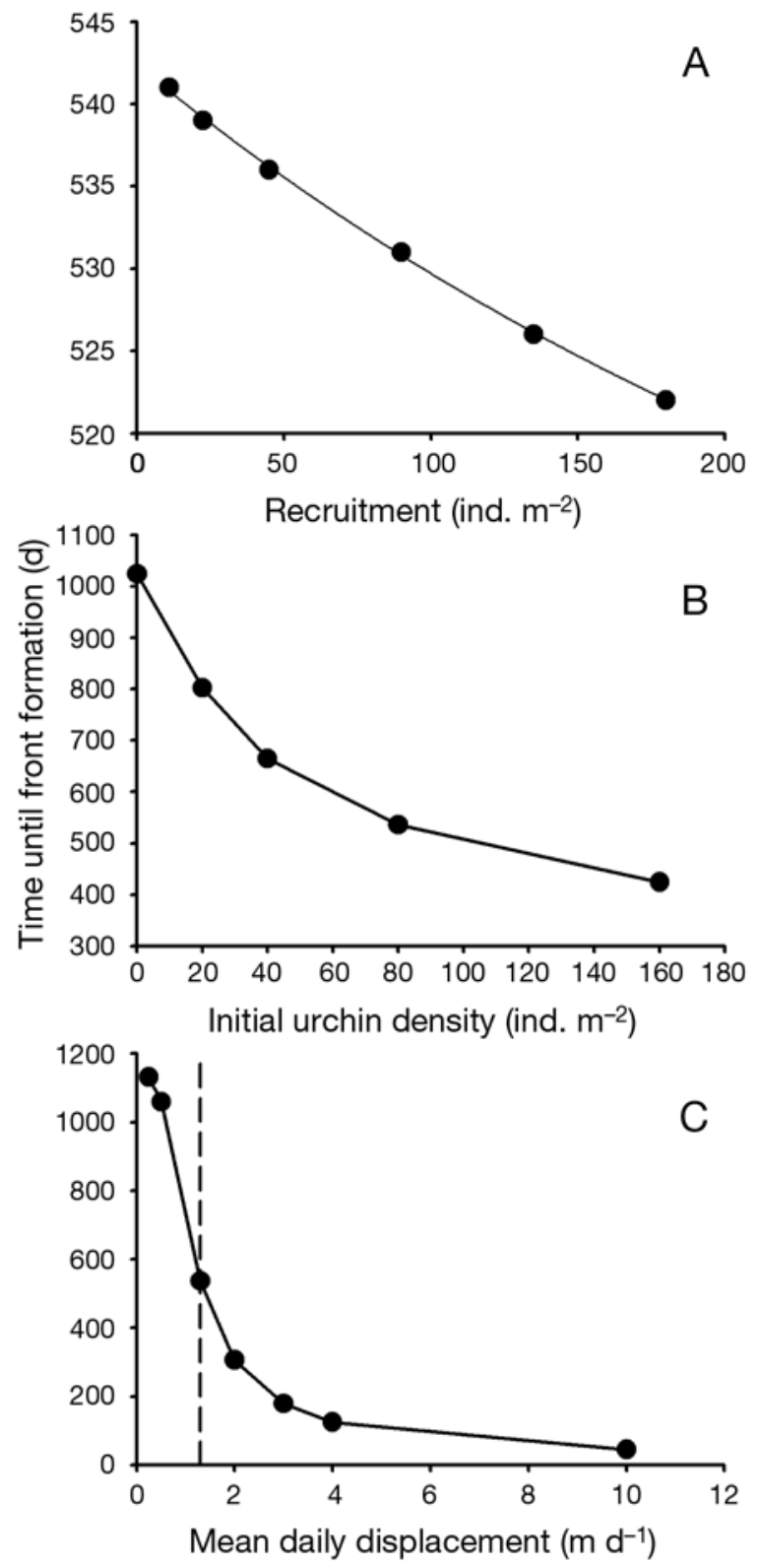

Fig. 6. Strongylocentrotus droebachiensis. Effect of (A) yearly recruitment of urchins, (B) initial urchin density in the refuge population, and (C) mean daily displacement of urchins on time needed for formation of a grazing front at Chebucto Head. The dashed line represents the value used in the main simulation

The initial density of urchins in the barrens refuge population at the start of the simulation affected the time to formation of a feeding front as well (Fig. 6B). Without urchins, the delay of $1023 \mathrm{~d}$ was the same as for very large distances between the refuge population and the kelp bed. At twice the average urchin density in the barrens ( 160 urchins $\left.\mathrm{m}^{-2}\right)$ in the refuge area, the delay was reduced by $21 \%$, from 536 to $425 \mathrm{~d}$.
Finally, the mean daily displacement of urchins also affected the time to front formation (Fig. 6C). Small changes around the value used in our simulation had a large effect on the time needed for formation of a front. Once the daily displacement exceeded $3 \mathrm{~m} \mathrm{~d}^{-1}$, the effect of displacement became negligible.

\section{Elasticity analysis}

Density of urchins in the front 2 yr following a mass mortality event was most sensitive to a change in daily displacement of urchins (Fig. 7A). A 10\% increase in daily displacement increased density of urchins at the front by $25 \%$. A $10 \%$ increase in annual survival of

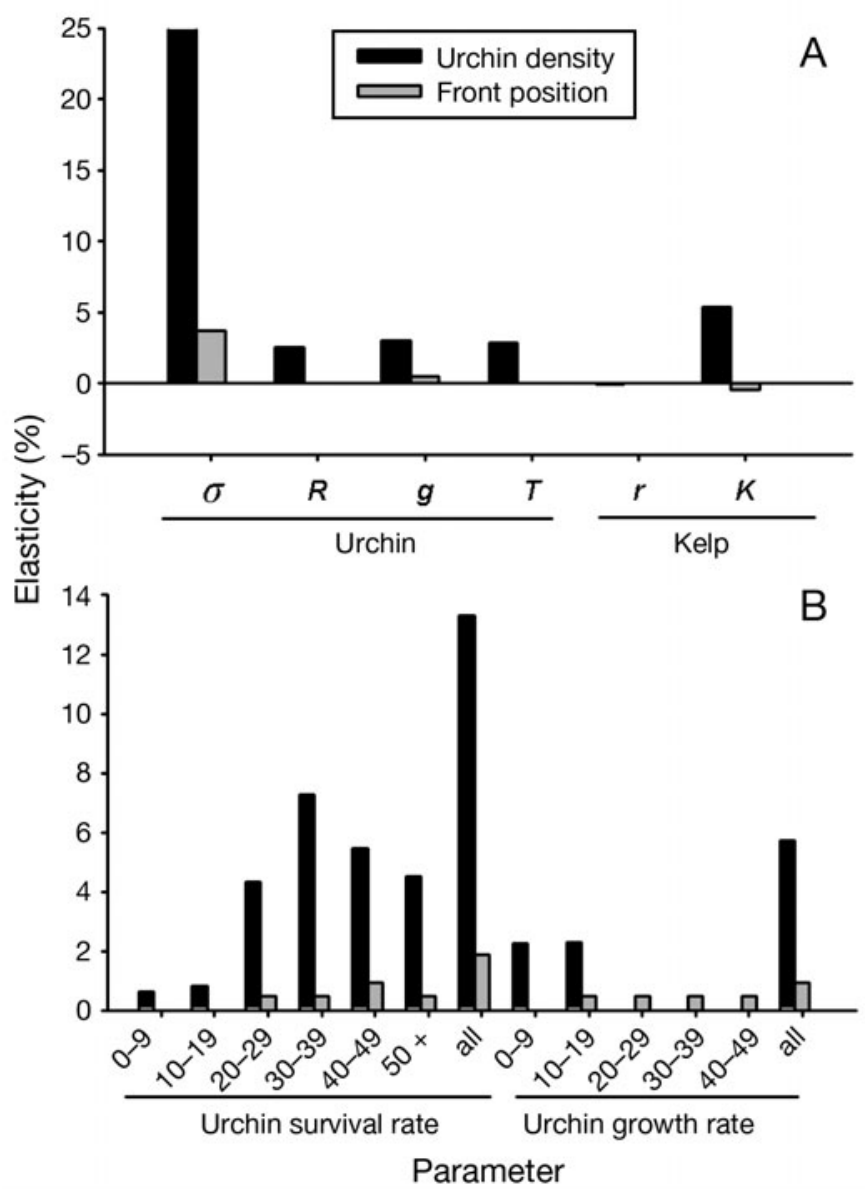

Fig. 7. Strongylocentrotus droebachiensis. Elasticity of density of urchins at the front and position of the front $2 \mathrm{yr}$ after a mass mortality event to a $10 \%$ increase in (A) non-size-specific model parameters, and in (B) the yearly survival and growth rates of urchins in each size class $(\mathrm{mm})$, as well as for all size classes together. Parameters in Panel A are standard deviation of the displacement distribution of urchins $(\sigma)$, urchin recruitment $(R)$, urchin grazing rate $(g)$, feeding threshold $(T)$, intrinsic growth rate of kelp $(r)$, and carrying capacity of the kelp bed $(K)$ (see also Table 1). Initial conditions were those observed at Chebucto Head in September 1999 
all urchin size classes increased density of urchins at the front by $13.3 \%$ (Fig. 7B). Most of this sensitivity was caused by survival of adult urchins in $u_{3}$ to $u_{6}$ ( $\geq 30 \mathrm{~mm}$ ). Increases in recruitment, feeding threshold, urchin growth rate (mostly by small urchins), urchin grazing rate, and kelp carrying capacity also resulted in increases in the density of urchins at the front, while an increase in kelp growth rate resulted in a slight decrease in urchin density (Fig. 7A,B).

Overall, the position of the front after 2 yr was robust to increases in the parameters of the model (Fig. 7A,B). The position of the front after $2 \mathrm{yr}$ was most sensitive to a $10 \%$ increase in daily displacement $(3.8 \%)$ and in survival $(1.9 \%)$ of all urchin size classes. The position of the front was more sensitive to increases in survival and growth of urchins $>20 \mathrm{~mm}$ than those $<20 \mathrm{~mm}$ (Fig. 7B). A $10 \%$ increase in kelp carrying capacity had a negative effect $(-0.47 \%)$ on the position of the front after 2 yr (Fig. 7A).

\section{DISCUSSION}

\section{Spatial population dynamics}

We previously developed a relatively simple foraging model that included the key components of the behaviour of Strongylocentrotus droebachiensis to predict the formation of a grazing front on short time scales (months) (Lauzon-Guay et al. 2008). Here, we have expanded this model to a longer time scale (years) and to include size-specific vital rates of urchins (growth, survival and contributions to recruitment). Our model predictions for time required for re-formation of a feeding front following urchin mass mortality and for position of this front over time corresponded well to field observations at 2 sites of differing bathymetry. More generally, our modelling exercise suggests that transitions between states can be predicted, which supports the notion that alternate states are not necessarily stochastic (Bertness et al. 2004).

The site at Chebucto Head is characterised by a steeply sloping bottom and, therefore, a short distance between the lower limit of the pre-existing kelp bed (before the urchin mass mortality) and the refuge population of urchins below $20 \mathrm{~m}$ depth. Our simulations showed that a front re-formed at the kelp bed-barrens interface in $<2 \mathrm{yr}$, which is consistent with observations at this site by Brady \& Scheibling (2005). Thus, urchin populations in steeply sloping areas are able to fill the gap left by the mass mortality in a relatively short period and prevent the kelp bed from extending to deeper waters. Our model over-estimated by $9 \mathrm{~m}$ the advance of the grazing front $3.5 \mathrm{yr}$ after the urchin mass mortality event. The steep slope (and short dis- tance between the kelp bed and the refuge population) at Chebucto Head resulted in a front forming in shallow waters (8 to $10 \mathrm{~m}$ depth). As an urchin front moves into shallow waters, wave action can have a negative effect on the movement and feeding of urchins that results in a slower rate of advance (Lauzon-Guay \& Scheibling 2007b). As our model does not include the effect of waves, we expect it to overestimate the rate of advance of feeding fronts in shallower waters.

At our other site, Splitnose Point, predicted values for the advance of the front 6 and $7 \mathrm{yr}$ after the urchin mass mortality event were, respectively, $9 \%$ greater and $6 \%$ lower than field observations. At this site, the thermal refuge for urchins was located $180 \mathrm{~m}$ away from the kelp bed, and, as a result, urchins were not able to re-colonize the gap rapidly enough to prevent the expansion of the kelp bed. Our simulation results suggested that the kelp bed had expanded its lower limit by $>100 \mathrm{~m} 3 \mathrm{yr}$ after urchin mass mortality. At that time, our model predicted that an urchin front had formed at the interface and that the kelp bed had already started to recede. Our model predicted that the lower limit of the kelp bed should be at $12 \mathrm{~m}$ depth by November 2005, which is only 4 mo later than the period we observed in the field (Lauzon-Guay \& Scheibling 2007a). In July 2006 ( 7 yr after urchin mass mortality), there was very good agreement between the predicted and observed lower limit of the kelp bed at Splitnose Point.

In a review of several sites along the Atlantic coast of Nova Scotia, Meidel \& Scheibling (2001) found that the highest densities of urchins $\left(136 \pm 46\right.$ urchins $\mathrm{m}^{-2}$, mean $\pm \mathrm{SE}$ ) are found at the front, while kelp beds have the lowest densities $\left(14 \pm 5\right.$ urchins $\mathrm{m}^{-2}$; Meidel \& Scheibling 2001). Densities in barrens tend to vary with distance from urchin fronts, and tend to be lower $\left(41 \pm 10\right.$ urchins $\left.^{-2}\right)$ in newly formed barrens (near the front) than in older barrens in deeper water $(71 \pm$ 6 urchins $\mathrm{m}^{-2}$; Meidel \& Scheibling 2001). Our model predicts a similar distribution pattern, with low urchin density in kelp beds, dense urchin fronts, and intermediate densities in barrens that increase with depth.

The 3 sub-populations are also characterised by differences in size structure. Most notably, a grazing front is typically composed of large adults (Bernstein et al. 1983, Scheibling \& Hatcher 2007), whereas urchins in barrens have a bimodal size distribution (Himmelman et al. 1983, Scheibling \& Stephenson 1984, Vadas et al. 2002, Brady \& Scheibling 2005). In the grazing front, our model predicted a bimodal distribution, although the mode for small juveniles was not observed in the field. The predicted size distribution of urchins in barrens showed the typical bimodality (with juvenile and adult modes). This conforms to the observed bimodal size distribution in the barrens behind the front at 
Chebucto Head in October 2002 (Brady \& Scheibling 2005). For both the front and barrens, our model predicted more small juveniles $\left(u_{1}\right)$ than were observed at Chebucto Head. The lack of small juveniles in the natural population may reflect a low recruitment rate at this time. Also, the bedrock ramp from which urchins were sampled (Brady \& Scheibling 2005) was largely featureless, providing few spatial refugia (in the form of scattered crevices) for small juveniles (R. E. Scheibling pers. obs.). Thus, the discrepancy between our model prediction and field observations at Chebucto Head likely reflects site- and date-specific contingences (particularly in terms of juveniles) that may not be characteristic of shallow habitats in general. Cannibalism of juveniles by large adults (Himmelman \& Steele 1971) may also reduce the number of juveniles, although we have not observed this in the field and did not include this as a process in our model. The exclusion of cannibalism may further explain the presence of a small mode of small juveniles predicted by our model in the front that was not observed in the field.

While various mechanisms have been suggested to explain bimodality in the size distribution of urchins in barrens, including different growth morphs (Vadas et al. 2002), size-specific predation (Himmelman et al. 1983, Keats 1991b, Scheibling 1996), size-specific growth (Himmelman 1986), and recruitment pulses (Ebert 1983), in our model, the bimodality in the barrens is caused by slower growth rates for small juveniles and large adults than for intermediate sizes, which results in a longer residence in the first and final size classes of the model. The difference in size structure between sub-populations can be explained by 2 non-exclusive mechanisms: (1) faster growth (because of the greater quantity and quality of food at the front) results in a shorter stay in the juvenile size class and (2) the sedentary behaviour of juveniles prevents them from moving with or into the front. Furthermore, a front is continuously moving away from areas of high juvenile density, since recruitment is lower in kelp beds than in barrens (Balch \& Scheibling 2000).

\section{Transition between kelp beds and barrens}

The spatial (depth) constraint of the perturbation caused by an epizootic prevents the complete eradication of urchins from the system. Thus, the inability of the pathogenic agent (Paramoeba invadens) to kill urchins at depths $>20 \mathrm{~m}$ (i.e. below the seasonal thermocline at temperatures $<10^{\circ} \mathrm{C}_{i}$ Scheibling \& Stephenson 1984) limits the stability of the kelp bed state. Inevitably, as urchins re-populate the shallow disease-affected areas, through recruitment and/or migration from deeper waters, the system undergoes a transitional phase in which both community states are present, albeit spatially segregated by the new perturbation (the grazing front) at their interface. The temporal scale of this transitional period depends on various physical (e.g. slope, topography, wave exposure) as well as biological (e.g. recruitment, growth, survival) factors that determine urchin abundance and foraging behaviour (Scheibling \& Hatcher 2007). Our analyses of factors affecting the time required for formation of a grazing front suggest that the state of the system prior to the perturbation in the barrens state (urchin mass mortality) influences the persistence of the kelp bed state. A high initial density of urchins in the deep barrens prior to the mass mortality can accelerate the formation of an urchin front at the lower margin of the kelp bed and, thereby, reduce the duration of the kelp bed state. In extreme situations, like that observed at Chebucto Head where a dense refuge population occurs in close proximity to the shallow disease-affected zone, urchins can rapidly re-populate the barrens area and prevent the establishment of the kelp bed state altogether.

The foraging behaviour of individual urchins also affects the persistence of the kelp bed state, as demonstrated by the effect of daily displacement on the time to formation of a grazing front. Many factors, such as wave action (Kawamata 1998, Lauzon-Guay \& Scheibling 2007b), density of conspecifics (Lauzon-Guay et al. 2006), food availability (Mattison et al. 1977), and substratum type (Dumont et al. 2006), influence the movement of urchins. The feeding rate of urchins and rate of advance of a front also are determined by the amount of food available (Lauzon-Guay \& Scheibling 2007a), as well as by wave action and water temperature (Lauzon-Guay \& Scheibling 2007b). Therefore, the persistence of the kelp bed state may be largely dependent on the particular conditions at a given site. In exposed areas, we could expect urchins to move and feed at a reduced rate because of wave action, allowing kelp beds to survive for protracted periods. A similar situation may occur where urchins dwell on sand or cobble bottoms, because movement rate is slower on these substrata (Dumont et al. 2006).

Without an external input of recruits, the dispersal of urchins from the refuge population alone would result in a more persistent kelp bed state, especially at sites with gradual slopes (i.e. long distances between the residual kelp bed and surviving populations). Therefore, the long planktotrophic period of sea urchin larvae (4 to 21 wk; Strathmann 1978, Hart \& Scheibling 1988), providing a long-range dispersal capability, is in part responsible for the local instability of the kelp bed state. Even after near eradication of urchins from extensive tracts of coastline, neighbouring populations can re-colonize barrens areas. Our model suggests that in $<3 \mathrm{yr}$, urchin recruitment alone could be sufficient 
to allow re-formation of a feeding front. Large-scale oceanographic features and local hydrodynamic regimes can result in retention or broad-scale transport of urchin larvae (Balch \& Scheibling 2000). The inherent variability in larval supply at multiple spatial and temporal scales will, in turn, affect urchin recruitment rate and, consequently, the persistence of kelp beds.

Our model predictions suggested that the rocky subtidal ecosystem of the Atlantic coast of Nova Scotia alternates between a stable (urchin barrens) and an unstable alternative state (kelp bed). In such a case, where stability of one state is limited, it becomes important to understand the mechanisms underlying transitions between states. This understanding can allow the development of predictive models that could be used in the management of ecosystems.

\section{Present and future stability of the system}

Recent declines in kelp biomass, resulting from the invasive bryozoan Membranipora membranacea that colonizes kelp and causes extensive die-back of the canopy (Scheibling et al. 1999, Levin et al. 2002), may accelerate the transition between kelp beds and barrens in invaded areas of the coast (Lauzon-Guay \& Scheibling 2007a). The transitional period between states is dependent on the urchin population size and, to a large extent, on the topography of a site. At a gently sloping site, the transition will take much longer than at a steeper site. During this transitional period both states co-exist, and a small change in urchin density at the front can speed up, slow down, or even stop the transition between states, while a much greater change in density (mass mortality) is required to reverse the trajectory.

Historically, the presence of large predatory fish may have regulated the stability of the aboriginal subtidal ecosystem in the Northwest Atlantic, by reducing urchin survival (Steneck 1997), similar to the keystone effect of sea otters in the Northeast Pacific (Estes \& Duggins 1995). Thus, a century of overfishing may have altered the coastal food web and the stability of the ecosystem (Jackson et al. 2001). Recently, overfishing of sea urchins in the Gulf of Maine has greatly depleted their populations and resulted in increased algal growth (Steneck et al. 2002). The community-level impacts of overfishing, of both sea urchins and their predators, highlights the need for ecosystem-based fisheries management (Pikitch et al. 2004), and a sound understanding of the stability and resilience of alternative community states (Scheffer et al. 2001) and of the mechanisms leading to transitions between states.

Our mathematical models elucidate important processes that structure communities and regulate transi- tions between them, and enable us to hindcast past and predict future conditions. The relatively high level of uncertainty in our model predictions, as well as the discrepancies between model predictions and field observations of the size structure of urchin populations, suggests caution in interpreting the longer term predictions of our model. Field experiments aimed at obtaining more precise estimates of model parameters (e.g. recruitment, growth, and movement of urchins) could alleviate these problems and increase confidence in model outputs for periods spanning several years to a decade. Nonetheless, our model could serve as a valuable tool for habitat-based management of the urchin fishery in Nova Scotia (Miller \& Nolan 2000) by estimating harvesting levels required to control the transition between kelp bed and barrens states. Mathematical models also may aid in understanding the increasingly complex dynamics of the urchin-kelp ecosystem of the Northwest Atlantic, where climate change, as well as recent invasions (by the bryozoan Membranipora membranacea and the green alga Codium fragile ssp. tomentosoides) appear to be altering the stability of the system or creating new alternative states, such as Codium meadows (Harris \& Tyrrell 2001, Chapman et al. 2002, Scheibling \& Gagnon 2006).

Acknowledgements. We thank J. Watmough and J. van de Koppel for their help and comments on the manuscript. This research was funded by a Discovery Grant from the Natural Sciences and Engineering Research Council of Canada (NSERC) to R.E.S. J.S.L.G. was supported by a Canadian Graduate Scholarship (NSERC), a doctoral scholarship from the Fonds Québécois de la Recherche sur la Nature et les Technologies, a Magee postgraduate merit award from the University of New Brunswick (UNB), Marguerite and Murray Vaughan graduate fellowships in Marine Sciences (UNB), and funding by the Network of Centres of Excellence for Mathematics of Information Technology and Complex Systems (MITACS, NSERC).

\section{LITERATURE CITED}

Balch T, Scheibling RE (2000) Temporal and spatial variability in settlement and recruitment of echinoderms in kelp beds and barrens in Nova Scotia. Mar Ecol Prog Ser 205: 139-154

Barbeau MA, Caswell H (1999) A matrix model for short-term dynamics of seeded populations of sea scallops. Ecol Appl 9:266-287

Beaudin M (2001) Towards greater value: enhancing eastern Canada's seafood industry. Canadian Institute for Research on Regional Development, Moncton

> Bernstein BB, Schroeter SC, Mann KH (1983) Sea urchin (Strongylocentrotus droebachiensis) aggregating behavior investigated by a subtidal multifactorial experiment. Can J Fish Aquat Sci 40:1975-1986

> Bertness MD, Trussell GC, Ewanchuck PJ, Silliman BR, Crain CM (2004) Consumer-controled community states on Gulf of Maine rocky shores. Ecology 85:1321-1331 
Brady SM, Scheibling RE (2005) Repopulation of the shallow subtidal zone by green sea urchins (Strongylocentrotus droebachiensis) following mass mortality in Nova Scotia, Canada. J Mar Biol Assoc UK 85:1511-1517

Breen PA, Mann KH (1976) Destructive grazing of kelp by sea urchins in eastern Canada. J Fish Res Board Can 33: $1278-1283$

Camp DK, Cobb SP, van Breedveld JF (1973) Overgrazing of seagrasses by a regular urchin, Lytechinus variegatus. BioScience 23:37-38

Caswell H (2001) Matrix population models, 2nd edn. Sinauer Associates, Sunderland, MA

> Chapman ARO (1981) Stability of sea urchin dominated barren grounds following destructive grazing of kelp in StMargarets Bay, eastern Canada. Mar Biol 62:307-311

> Chapman ARO, Johnson CR (1990) Disturbance and organization of macroalgal assemblages in the Northwest Atlantic. Hydrobiologia 192:77-121

Chapman AS, Scheibling RE, Chapman ARO (2002) Species introductions and changes in marine vegetation of Atlantic Canada. In: Claudi R, Nantel P, Muckle-Jeffs E (eds) Alien invaders in Canada's waters, wetlands and forests. Natural Resources Canada, Canadian Forest Service Branch, Ottawa, p 133-148

Chen Y, Hunter M (2003) Assessing the green sea urchin (Strongylocentrotus droebachiensis) stock in Maine, USA. Fish Res 60:527-537

Dayton PK (1985) Ecology of kelp communities. Annu Rev Ecol Syst 16:215-245

> Dumont C, Himmelman JH, Russell MP (2004) Size-specific movement of green sea urchins Strongylocentrotus droebachiensis on urchin barrens in eastern Canada. Mar Ecol Prog Ser 276:93-101

Dumont CP, Himmelman JH, Russell MP (2006) Daily movement of the sea urchin Strongylocentrotus droebachiensis in different subtidal habitats in eastern Canada. Mar Ecol Prog Ser 317:87-99

Ebert TA (1983) Recruitment in echinoderms In: Jangoux M, Lawrence JM (eds) Echinoderm studies. AA Balkema, Rotterdam, p 169-203

> Ebert TA, Russell MP (1993) Growth and mortality of subtidal red sea urchins, (Strongylocentrotus franciscanus) at San Nicolas Island, California, USA: problems with models. Mar Biol 117:79-89

Estes JA, Duggins DO (1995) Sea otters and kelp forests in Alaska: generality and variation in a community ecological paradigm. Ecol Monogr 65:75-100

Estes JA, Palmisano JF (1974) Sea otters: their role in structuring nearshore communities. Science 185:1058-1060

Evans M, Hastings N, Peacock B (2000) Statistical distributions. John Wiley and Sons, New York

Folke C, Carpenter SR, Walker B, Scheffer M, Elmqvist T, Gundersonand L, Holling CS (2004) Regime shifts, resilience and biodiversity in ecosystem management. Annu Rev Ecol Evol Syst 35:557-581

Foreman RE (1977) Benthic community modification and recovery following intensive grazing by Strongylocentrotus droebachiensis. Helgol Meeresunters 30:468-484

Gaylord B, Reed DC, Washburn L, Raimondi PT (2004) Physical-biological coupling in spore dispersal of kelp forest macroalgae. J Mar Syst 49:19-39

- Harris LG, Tyrrell MC (2001) Changing community states in the Gulf of Maine: synergism between invaders, overfishing and climate change. Biol Invasions 3:9-21

Hart MW, Scheibling RE (1988) Heat waves, baby booms, and the destruction of kelp beds by sea urchins. Mar Biol 99: 167-176
Himmelman JH (1986) Population biology of green sea urchins on rocky barrens. Mar Ecol Prog Ser 33:295-306

Himmelman JH, Steele DH (1971) Foods and predators of the green sea urchin Strongylocentrotus droebachiensis in Newfoundland waters. Mar Biol 9:315-322

Himmelman JH, Lavergne Y, Axelsen F, Cardinal A, Bourget E (1983) Sea urchins in the St. Lawrence estuary: their abundance, size-structure, and suitability for commercial exploitation. Can J Fish Aquat Sci 40:474-486

Holling CS (1973) Resilience and stability of ecological systems. Annu Rev Ecol Syst 4:1-24

> Hughes TP, Bellwood DR, Folke C, Steneck RS, Wilson J (2005) New paradigms for supporting the resilience of marine ecosystems. Trends Ecol Evol 20:380-386

Jackson JB, Kirby MX, Berger WH, Bjorndal KA and others (2001) Historical overfishing and the recent collapse of coastal ecosystems. Science 293:629-638

Jellett JF, Scheibling RE (1988) Effect of temperature and prey availability on growth of Paramoeba invadens in monoxenic culture. Appl Environ Microbiol 54: 1848-1854

Johnson CR, Mann KH (1982) Adaptations of Strongylocentrotus droebachiensis for survival on barren grounds in Nova Scotia. In: Lawrence JM (ed) Echinoderms: Proc Int Conf, Sep 14-17, Tampa Bay. AA Balkema, Rotterdam, p 277-283

> Johnson CR, Mann KH (1988) Diversity, patterns of adaptation, and stability of Nova Scotian kelp beds. Ecol Monogr 58:129-154

Jones GM, Scheibling RE (1985) Paramoeba sp. (Amebida, Paramoebidae) as the possible causative agent of seaurchin mass mortality in Nova Scotia. J Parasitol 71: 559-565

Kawamata S (1998) Effect of wave-induced oscillatory flow on grazing by a subtidal sea urchin Strongylocentrotus nudus (A. Agassiz). J Exp Mar Biol Ecol 224:31-48

Keats DW (1991a) Refugial Laminaria abundance and reduction in urchin grazing in communities in the north-west Atlantic. J Mar Biol Assoc UK 71:867-876

> Keats DW (1991b) American plaice, Hippoglossoides platessoides (Fabricius), predation on green sea urchins, Strongylocentrotus droebachiensis (OF Muller), in eastern Newfoundland. J Fish Biol 38:67-72

Knowlton N (1992) Thresholds and multiple stable states in coral reef community dynamics. Am Zool 32:674-682

Kot M, Lewis MA, van den Driessche P (1996) Dispersal data and the spread of invading organisms. Ecology 77 : 2027-2042

Lamare MD, Mladenov PV (2000) Modelling somatic growth in the sea urchin Evechinus chloroticus (Echinoidea: Echinometridae). J Exp Mar Biol Ecol 243:17-43

Lauzon-Guay JS, Scheibling RE (2007a) Behaviour of sea urchin Strongylocentrotus droebachiensis grazing fronts: food-mediated aggregation and density-dependent facilitation. Mar Ecol Prog Ser 329:191-204

Lauzon-Guay JS, Scheibling RE (2007b) Seasonal variation in movement, aggregation and destructive grazing of the green sea urchin (Strongylocentrotus droebachiensis) in relation to wave action and sea temperature. Mar Biol 151: 2109-2118

> Lauzon-Guay JS, Scheibling RE, Barbeau MA (2006) Movement patterns in the green sea urchin, Strongylocentrotus droebachiensis. J Mar Biol Assoc UK 86:167-174

Lauzon-Guay JS, Scheibling RE, Barbeau MA (2008) Formation and propagation of feeding fronts in benthic marine invertebrates: a modeling approach. Ecology 89: 3150-3162 
Lawrence JM (1975) On the relationships between marine plants and sea urchins. Oceanogr Mar Biol Annu Rev 13: 213-286

Levin PS, Coyer JA, Petrik R, Good TP (2002) Communitywide effects of nonindigenous species on temperate rocky reefs. Ecology 83:3182-3193

Lewontin RC (1969) The meaning of stability. Brookhaven Symp Biol 22:13-24

Manly BFG (1997) Randomization, bootstrap and Monte Carlo methods in biology, 2nd edn. Chapman \& Hall, New York

Mann KH (1972) Ecological energetics of the sea-weed zone in a marine bay on the Atlantic coast of Canada. II. Productivity of the seaweeds. Mar Biol 14:199-209

Mattison JE, Trent JD, Shanks AL, Akin TB, Pearse JS (1977) Movement and feeding activity of red sea urchins (Strongylocentrotus franciscanus) adjacent to a kelp forest. Mar Biol 39:25-30

Meidel SK, Scheibling RE (1998) Annual reproductive cycle of the green sea urchin, Strongylocentrotus droebachiensis, in differing habitats in Nova Scotia, Canada. Mar Biol 131:461-478

Meidel SK, Scheibling RE (2001) Variation in egg spawning among subpopulations of sea urchins Strongylocentrotus droebachiensis: a theoretical approach. Mar Ecol Prog Ser 213:97-110

Miller RJ (1985) Succession in sea urchin and seaweed abundance in Nova Scotia, Canada. Mar Biol 84:275-286

Miller RJ, Nolan SC (2000) Management of the Nova Scotia sea urchin fishery: a nearly successful habitat based management regime. Research Document 2000/109, Canadian Stock Assessment Secretariat, Ottawa

> Mohn RK, Miller RJ (1987) A ration-based model of a seaweed sea-urchin community. Ecol Modell 37:249-267

Neubert MG, Caswell H (2000) Demography and dispersal: calculation and sensitivity analysis of invasion speed for structured populations. Ecology 81:1613-1628

Pikitch EK, Santora C, Babcock EA, Bakun A and others (2004) Ecosystem-based fishery management. Science 305:346-347

Raymond BG, Scheibling RE (1987) Recruitment and growth of the sea urchin Strongylocentrotus droebachiensis (Muller) following mass mortalities off Nova Scotia, Canada. J Exp Mar Biol Ecol 108:31-54

Rowley RJ (1989) Settlement and recruitment of sea urchins (Strongylocentrotus spp.) in a sea urchin barren ground and a kelp bed-Are populations regulated by settlement or post-settlement processes? Mar Biol 100: 485-494

Russell MP, Ebert TA, Petraitis PS (1998) Field estimates of growth and mortality of the green sea urchin, Strongylocentrotus droebachiensis. Ophelia 48:137-153

Scheffer M, Carpenter S, Foley J, Folke C, Walker B (2001) Catastrophic shifts in ecosystems. Nature 413:591-596

Scheibling RE (1986) Increased macroalgal abundance following mass mortalities of sea urchins (Strongylocentrotus

Editorial responsibility: Romuald Lipcius,

Gloucester Point, Virginia, USA droebachiensis) along the Atlantic coast of Nova Scotia. Oecologia 68:186-198

Scheibling RE (1996) The role of predation in regulating sea urchin populations in eastern Canada. Oceanol Acta 19: 421-430

- Scheibling RE, Gagnon P (2006) Competitive interactions between the invasive green alga Codium fragile ssp. tomentosoides and native canopy-forming seaweeds in Nova Scotia (Canada). Mar Ecol Prog Ser 325:1-14

Scheibling RE, Hatcher BG (2007) The ecology of Strongylocentrotus droebachiensis. In: Lawrence JM (ed) Edible sea urchins: biology and ecology. Elsevier B.V., Amsterdam, p 353-392

Scheibling RE, Hennigar AW (1997) Recurrent outbreaks of disease in sea urchins Strongylocentrotus droebachiensis in Nova Scotia: evidence for a link with large-scale meteorologic and oceanographic events. Mar Ecol Prog Ser 152:155-165

Scheibling RE, Stephenson RL (1984) Mass mortality of Strongylocentrotus droebachiensis (Echinodermata: Echinoidea) off Nova Scotia, Canada. Mar Biol 78:153-164

Scheibling RE, Hennigar AW, Balch T (1999) Destructive grazing, epiphytism, and disease: the dynamics of sea urchin-kelp interactions in Nova Scotia. Can J Fish Aquat Sci 56:2300-2314

Simenstad CA, Estes JA, Kenyon KW (1978) Aleuts, sea otters, and alternate stable-state communities. Science 200:403-411

- Sivertsen K (1997) Geographic and environmental factors affecting the distribution of kelp beds and barren grounds and changes in biota associated with kelp reduction at sites along the Norwegian coast. Can J Fish Aquat Sci 54: 2872-2887

Steneck RS (1997) Fisheries-induced biological changes to the structure and function of the Gulf of Maine ecosystem. In: Wallace GT, Braasch EF (eds) Proc Gulf of Maine Ecosystem Dynamics Scientific Symposium and Workshop. Regional Association for Research on the Gulf of Maine Report 97-1, Hanover, NH, p 151-165

Steneck RS, Graham MH, Bourque BJ, Corbett D, Erlandson JM, Estes JA, Tegner MJ (2002) Kelp forest ecosystems: biodiversity, stability, resilience and future. Environ Conserv 29:436-459

Strathmann RR (1978) Length of pelagic period in echinoderms with feeding larvae from the northwest Pacific. J Exp Mar Biol Ecol 34:23-27

Sutherland JP (1974) Multiple stable points in natural communities. Am Nat 108:859-873

Turchin P (2003) Complex population dynamics: a theoretical/ empirical synthesis. Princeton University Press, Princeton, NJ

Vadas RL, Smith BD, Beal B, Dowling T (2002) Sympatric growth morphs and size bimodality in the green sea urchin (Strongylocentrotus droebachiensis). Ecol Monogr 72:113-132

Submitted: February 7, 2008; Accepted: September 26, 2008 Proofs received from author(s): December 19, 2008 